\title{
Fabrication and characterization of palm sugar tree (Arenga pinnata) fiber composites reinforced by polyester resin
}

\author{
Timbangen Sembiring ${ }_{1}^{1,2}$, Evi Sitepu ${ }^{1}$, Martha Rianna ${ }^{1}$, Aditia \\ Warman Singarimbun ${ }^{1}$, Perdinan Sinuhaji ${ }^{1}$, Kerista Sebayang ${ }^{1}$ \\ ${ }^{1}$ Department of Physics, Universitas Sumatera Utara, Medan, Indonesia \\ ${ }^{2}$ Nanomedicine Center of Innovation, Universitas Sumatera Utara, \\ Medan, Indonesia
}

Received December 22, 2018

\begin{abstract}
Palm sugar tree (Arenga pinnata) fiber composites reinforced by polyester resin have been obtained and characterized as an alternative material for neutron beam shield. The content of sugar palm fiber was varied by $0,5,10,15$ and $20 \%$ of volume fraction, which was strongly related to the physical and mechanical properties. The maximum value of mechanical properties of the composites was found to be at $10 \%$. The average results on chemical composition of sugar palm tree fiber showed cellulose, hemicelluloses, and lignin content of $47.8 \%, 6.5 \%, 22.3 \%$, respectively. As a result of neutron activation analysis, several elements were identified, such as $\mathrm{Cl}, \mathrm{Mn}, \mathrm{K}, \mathrm{Br}, \mathrm{La}, \mathrm{Cr}, \mathrm{Fe}, \mathrm{Hg}$, Sc and $\mathrm{Zn}$, in the composite containing sugar palm fibers enforced by polyester resin. A possibility was studied to use this material for protection from thermal neutrons.The counts of neutron beams decreased as the content of sugar palm fibers increased. This fact implies that the composites containing sugar palm fibers can be used as shield materials for neutron beams.
\end{abstract}

Keywords: sugar palm tree fiber, composites, mechanical properties, neutron radiation shielding.

Получены и исследованы волокнистые композиты на основе пальмового дерева (Arenga pinnata), армированного полиэфирной смолой. Составы сахарного пальмового волокна варьировали в пределах $0,5,10,15$ и $20 \%$ от объемной доли. Наилучшие механические свойства композитов получены при $10 \%$. Определен химический состав композитов, содержание целлюлозы, гемицеллюлозы и лигнина составляет 47,8 \%, 6,5\%, $22,3 \%$, соответственно. Методом нейтронно-активационного анализа определено наличие в данном композите элементов $\mathrm{Cl}, \mathrm{Mn}, \mathrm{K}, \mathrm{Br}, \mathrm{La}, \mathrm{Cr}, \mathrm{Fe}, \mathrm{Hg}, \mathrm{Sc}$ и $\mathrm{Zn}$. Благодаря повышенному содержания лигнина (углерода) исследована возможность использования данного материала для защиты от тепловых нейтронов. Показано, что интенсивность нейтронных пучков уменьшается с увеличением содержания волокон сахарной пальмы. Из этого факта следует, что композиты, содержащие волокна сахарной пальмы, могут быть использованы в качестве защитных материалов для нейтронных пучков.

Виготовлення та характеристика волокнистих композитів з пальмового дерева (Arenga pinnata), армованих поліефірною смолою. Timbangen Sembiring, Evi Sitepu, Martha Rianna, Aditia Warman Singarimbun, Perdinan Sinuhaji, Kerista Sebayang.

Отримано і досліджено волокнисті композити на основі пальмового дерева (Arenga pinnata), армованого поліефірною смолою. Склади цукрового пальмового волокна варіювали у межах $0,5,10,15$ і 20 \% від об'ємної частки. Найкращі механічні властивості композитів отримано при $10 \%$. Визначено хімічний склад композитів, вміст целюлози, геміцелюлози і лігніну становить 47,8 \%, 6,5 \%, 22,3 \% відповідно. Методом нейтронно-активаційного аналізу визначено наявність у даному композиті еле- 
ментів Cl, Mn, K, Br, La, Cr, Fe, Hg, Sc i Zn. Досліджено можливість використання даного матеріалу для захисту від теплових нейтронів. Показано, що інтенсивність нейтронних пучків зменшується зі збільшенням вмісту цукрової пальми. 3 цього випливає, що композити, що містять волокна цукрової пальми, можуть бути використані в якості захисних матеріалів для нейтронних пучків.

\section{Introduction}

Sugar palm (Arenga pinnata) fiber is a natural fiber derived from Arenga pinnata trees which were abundantly grown normally in tropical and humid country like Southeast Asia [1]. This plant is a multipurpose palm species from which a variety of foods and beverages, timber commodities, biofibers, biopolymers and biocomposites can be produced. Recently, it is being used as a source of renewable energy in the form of bio-ethanol via fermentation process of the sugar palm sap. There is a great opportunity to develop this plant to produce alcohol fuel in countries like Indonesia and Malaysia [2] because sugar palm trees are available in abundance. The wastes from sugar palm trees are feasible to be used as fibers and fillers in polymeric composites [3]. Although numerous products can be produced from sugar palm, three products that are most prominent are palm sugar, fruits and fibers. It has been known that they are highly durable, resistant to sea water. They are available naturally in the form of woven fiber and are easy to process. To recognize the strength and weakness of natural fiber composite, it is necessary to comprehend the physical, mechanical and thermal properties of the fibers. Several researches have been studied on the chemical and physical properties of sugar palm fiber [4]. Chemically, the composition of sugar palm fiber consists of cellulose, hemicellulose, lignin, ash and other with composition varies by height of the trees [5,6]. The cellulose, hemicellulose, lignin have the high of carbon composition $\mathrm{B}, \mathrm{C}, \mathrm{Li}, \mathrm{He}$ are element content used for neutron absorption [7]. These constituent of plant fiber contain the stored chemical energy, which varies from plant to plan [8]. Looking at the proportion of the composition, the cellulose is the main constituent of natural fiber, and it provides mechanical strength [9]. The physical properties of sugar palm fiber and wellestablished natural fibers such as jute, ramie, sisal, coir and kenaf were compiled by several authors [10-12]. In this paper focuses mainly on the fabrication and characterization of sugar palm tree composite as an alternative for shielding material for absorbing neutron beam.

\section{Materials and methods}

Sugar palm fibers were obtained from Desa Sembahe, Kecamatan Sibolangit, Kabupaten Deli Serdang. The sugar palm trees were chosen based on the average age categorized as pre productive (about less than 4 years in age), productive (between 4-7 years in age) and post productive (older than 7 years in age) sugar palm. Those palm trees are cut in to three different parts: bottom part, middle part and upper part.

Remaining parts of each sample were used for the chemical content analysis. All the samples were cut into pieces of $10 \times 4 \times 2 \mathrm{~cm}^{3}$ size, and then dried directly under sun light for about 2 weeks. After drying, each type of sample was immersed into $15 \% \mathrm{NaOH}$ solution for $24 \mathrm{~h}$ to extract the fibers from chemical components. After that the fibers were separated and again dried under sun light for two days. The various compositions of sugar palm tree fibers were of $0,5,10,15$, and $20 \%$. Each sample was then compacted in molten state by reinforcing with high impact polystyrene (HIPS) having a density of $1.04 \mathrm{~g} / \mathrm{cm}^{3}$ as the polymer matrix.

To determine the decrease in neutron absorption by irradiating the target (sample) that was been arranged on the $\mathrm{Pb}$ plate with a neutron beam for $18 \mathrm{~h}$, then chopped using a gamma spectrometer at the Neutron Activation Analysis (NAA) Laboratory.

\section{Results and discussion}

\subsection{Chemical composition}

Chemical composition of sugar palm obtained from different age of the palm tree is summarized in the Table 1 .

It can be seen from Table 1 that cellulose, hemicelluloses, and lignin contents increased with the increase of the age of trees. It is similar to [13] with cellulose, hemicelluloses, and lignin contents of $37.3 \%, 4.71 \%, 17.93 \%$. A good correlation between chemical composition and mechanical properties of sugar palm fiber was found where cellulose, lignin, and hemicelluloses show a significant contribution to the increase in tensile strength, modulus, and elongation at break of the fiber, respectively. 
Table 1. Chemical composition of sugar palm trees

\begin{tabular}{||c|c|c|c||}
\hline Composition & $\begin{array}{c}\text { Pre } \\
\text { productive } \\
\text { palm }\end{array}$ & $\begin{array}{c}\text { Productive } \\
\text { Palm }\end{array}$ & $\begin{array}{c}\text { Post } \\
\text { productive } \\
\text { palm }\end{array}$ \\
\hline Cellulose (\%) & 44.33 & 48.12 & 51.06 \\
Hemicellulose (\%) & 6.06 & 6.44 & 6.95 \\
Lignin (\%) & 19.2 & 23.06 & 24.64 \\
Moisture (\%) & 6.06 & 6.92 & 7.42 \\
Extractive (\%) & 2.12 & 1.84 & 1.12 \\
Ash (\%) & 22.23 & 13.74 & 8.81 \\
Bulk Density & 1.19 & 1.23 & 1.26 \\
$\left(\mathrm{~g} / \mathrm{cm}^{3}\right)$ & & & \\
\hline
\end{tabular}

\subsection{Physical properties}

The bulk density of composite materials was determined by measuring the weight and dimension of the composite samples based on the following relation:

$$
D=\frac{W_{t}}{L \cdot W \cdot H}
$$

where $W_{t}, L, W$ and $H$ are weight, length, width and height of sample composite, respectively. All the samples were dried at the temperature of $50^{\circ} \mathrm{C}$ for $24 \mathrm{~h}$ before measuring the density. Average densities were obtained using results from ten samples of each group. The water absorption ability of the palm fiber reinforced with high impact polystyrene composites was performed based on the ASTM D 570-98. For this purpose, each sample was soaked in to four glass beakers for $5 \%, 10 \%, 15 \%$ and $20 \%$ of water at room temperature [1]. The weight of the samples was measured before immersion of the samples. After certain period of time interval samples were taken out from the beaker glass, wiped out using tissue papers and then weighed. The water uptake (mass gained) was measured by subtraction of initial weight from the final weight [12]. The percentage of water absorption was calculated by the following relation:

$$
W_{s}=\frac{W_{f}-W_{i}}{W_{i}} \cdot 100 \%,
$$

where $W_{f}$ and $W_{i}$ are the weight of samples after and before soaking in to water.

\subsection{Mechanical properties}

Tensile and flexural properties of composites were measured by a universal test-
Table 2. Physical and mechanical properties of the composites for pre productive sugar palm

\begin{tabular}{||c|c|c|c|c|c||}
\hline $\begin{array}{c}\text { Fiber } \\
\text { content } \\
\text { (wt \%) }\end{array}$ & $\begin{array}{c}\text { Tensile } \\
\text { strength } \\
\text { (MPa) }\end{array}$ & $\begin{array}{c}\text { Strain } \\
\text { (MPa) }\end{array}$ & $\begin{array}{c}\text { Flexural } \\
\text { stress } \\
\text { (MPa) }\end{array}$ & $\begin{array}{c}\text { Vicker's } \\
\text { hardness }\end{array}$ & $\begin{array}{c}\text { Bulk } \\
\text { density } \\
\left(\mathrm{g} / \mathrm{cm}^{3}\right)\end{array}$ \\
\hline 0 & 26.17 & 5.12 & 51.22 & 12.67 & 1.04 \\
5 & 16.04 & 3.98 & 46.88 & 12.01 & 0.924 \\
10 & 20.22 & 4.66 & 48.92 & 11.66 & 0.909 \\
15 & 22.40 & 4.22 & 45.42 & 10.18 & 0.894 \\
20 & 19.38 & 4.05 & 42.01 & 9.82 & 0.887 \\
\hline
\end{tabular}

Table 3. Physical and mechanical properties of the composites for productive sugar palm

\begin{tabular}{|c|c|c|c|c|c||}
\hline \hline $\begin{array}{c}\text { Fiber } \\
\text { content } \\
\text { (wt \% ) }\end{array}$ & $\begin{array}{c}\text { Tensile } \\
\text { strength } \\
\text { (MPa) }\end{array}$ & $\begin{array}{c}\text { Strain } \\
\text { (MPa) }\end{array}$ & $\begin{array}{c}\text { Flexural } \\
\text { stress } \\
\text { (MPa) }\end{array}$ & $\begin{array}{c}\text { Vicker's } \\
\text { hardness }\end{array}$ & $\begin{array}{c}\text { Bulk } \\
\text { density } \\
\left(\mathrm{g} / \mathrm{cm}^{3}\right)\end{array}$ \\
\hline 0 & 32.26 & 6.78 & 62.60 & 13.21 & 1.04 \\
5 & 21.44 & 4.48 & 56.19 & 12.86 & 0.994 \\
10 & 27.65 & 5.60 & 58.41 & 11.54 & 0.982 \\
15 & 25.72 & 5.78 & 55.06 & 10.98 & 0.990 \\
20 & 23.20 & 4.95 & 48.64 & 10.02 & 0.997 \\
\hline
\end{tabular}

Table 4. Physical and mechanical properties of the composites for post productive sugar palm

\begin{tabular}{||c|c|c|c|c|c||}
\hline $\begin{array}{c}\text { Fiber } \\
\text { content } \\
\text { (wt \%) }\end{array}$ & $\begin{array}{c}\text { Tensile } \\
\text { strength } \\
(\mathrm{MPa})\end{array}$ & $\begin{array}{c}\text { Strain } \\
(\mathrm{MPa})\end{array}$ & $\begin{array}{c}\text { Flexural } \\
\text { stress } \\
(\mathrm{MPa})\end{array}$ & $\begin{array}{c}\text { Vicker's } \\
\text { hardness }\end{array}$ & $\begin{array}{c}\text { Bulk } \\
\text { density } \\
\left(\mathrm{g} / \mathrm{cm}^{3}\right)\end{array}$ \\
\hline 0 & 37.22 & 8.12 & 63.20 & 13.87 & 1.04 \\
5 & 25.04 & 5.98 & 58.63 & 12.26 & 0.991 \\
10 & 31.12 & 6.80 & 60.82 & 11.22 & 0.956 \\
15 & 30.86 & 6.58 & 57.13 & 10.46 & 0.941 \\
20 & 26.55 & 5.13 & 52.55 & 9.72 & 0.922 \\
\hline \hline
\end{tabular}

ing machine (Hounsfield UTM $10 \mathrm{KN}$, ASTM D 3039/D 3039 M-00) at a cross head speed of $2 \mathrm{~mm} / \mathrm{min}$, keeping a gauge length of $50 \mathrm{~mm}$ [13]. The percentages of flexural stress and strain were also measured by the same machine, keeping a distance of $70 \mathrm{~mm}$ between two supports on which the samples were placed to employ load. All the samples were tested under conditions of $50^{\circ} \mathrm{C}$. On the other hand, a software controlled Vicker's square based diamond indentor (Shimadzu) was used to measure the micro hardness $(H)$ from the residual impression on the sample surface after an indention time of $8 \mathrm{sec}$ to derive a load indention value of $H$ in MPa by the following relation:

$$
H=K \cdot \frac{P}{d^{2}},
$$




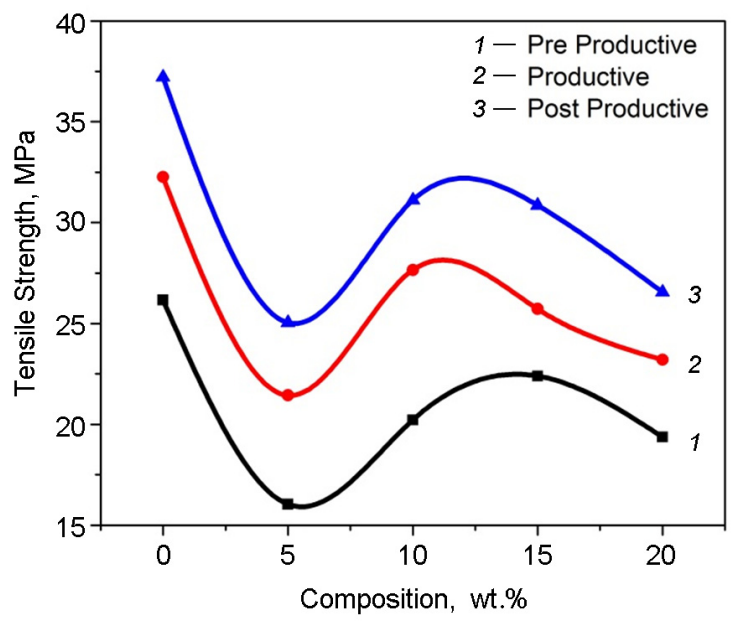

Fig. 1. The relationship between tensile strength and various composition of sugar palm fiber for pre productive, productive and post productive sugar palm.

where $d(\mathrm{~m})$ is the length of indentation diagonal, $P(N)$ is the applied load and $K$ is a geometrical factor equal to 1.891. Flat and smooth surface samples were used to measure the value of $H$. Five times of imprints were taken on each sample surface for each load and the value of $H$ was calculated from the average measurements [14]. Density and mechanical properties of the reinforced sugar palm composite are summarized in the Table 2-4.

It was noticed that cellulose, hemicelluloses, and lignin contents increased with the increase of the age of trees. A good correlation between chemical composition and mechanical properties of sugar palm fiber was found where cellulose, lignin, and hemicelluloses showed a significant contribution to the increase in tensile strength, modulus, and elongation at break of the fiber, respectively (Fig. 1-3).

The figures show that the highest value of tensile strength, strain, flectural stress was found for each composites of $10 \%$ of fiber tree. The tensile strengths were 20.22 $\mathrm{MPa}, 27.65 \mathrm{MPa}$ and $31.12 \mathrm{MPa}$ for the pre productive, productive and post productive sugar palm trees, respectively. The value of strain for the sample containing $10 \%$ fiber tree were $5.12 \mathrm{MPa}, 6.78 \mathrm{MPa}$ and $8.12 \mathrm{MPa}$ for the pre productive, productive and post productive sugar palm trees, respectively. Furthermore, the value of flexural stress were measured to be $51.22 \mathrm{MPa}, 62.60 \mathrm{MPa}$ and $63.20 \mathrm{MPa}$ for the pre productive, productive and post productive sugar palm trees, respectively

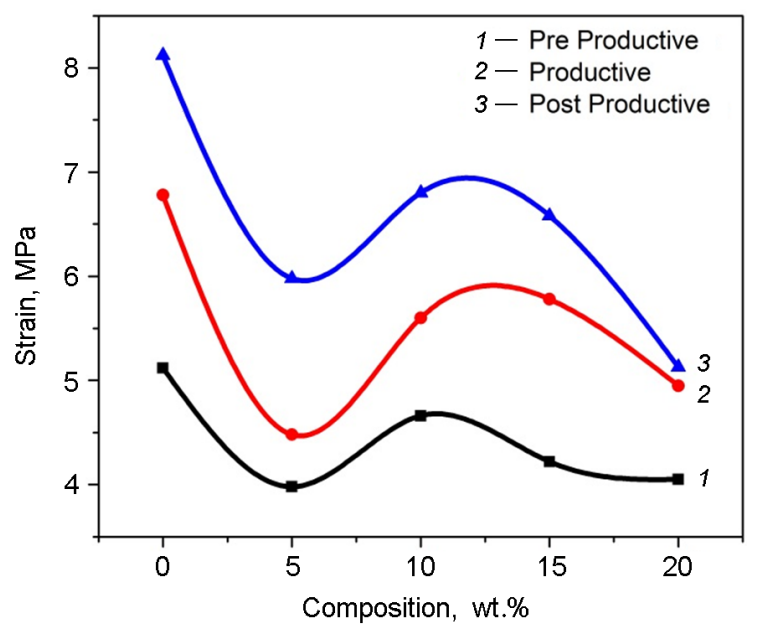

Fig. 2. The relationship between strain and various composition of sugar palm fiber for pre productive, productive and post productive sugar palm.

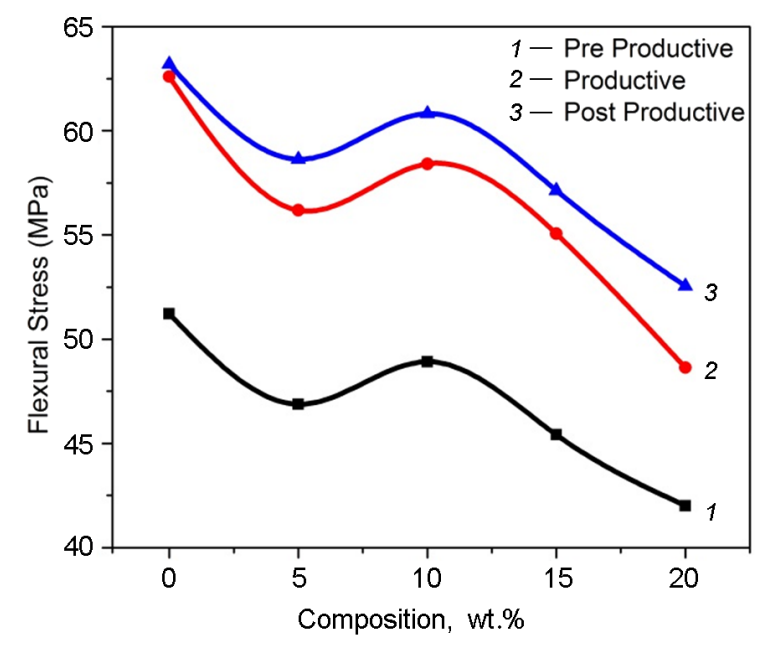

Fig. 3. The relationship between flexural stress and various composition of sugar palm fiber for pre-productive, productive and post productive sugar palm.

(Fig. 4). Natural fiber and their composites are renewable and environmental friendly. However, a drawback is that, due to high moisture absorption properties, there are formations of void in the composites which can reduce the mechanical properties of composite such as flexural strength.

\subsection{Neutron activation analysis}

Before neutron experiment was carried out, firstly, constant rate of the flux neutron had to be tested to obtain the accuracy of flux neutron by using $\gamma$-ray standard from the sources of Co-56 and Co-60. Based from Neutron Activation Analysis (NAA) analyzed from the sugar palm fiber 


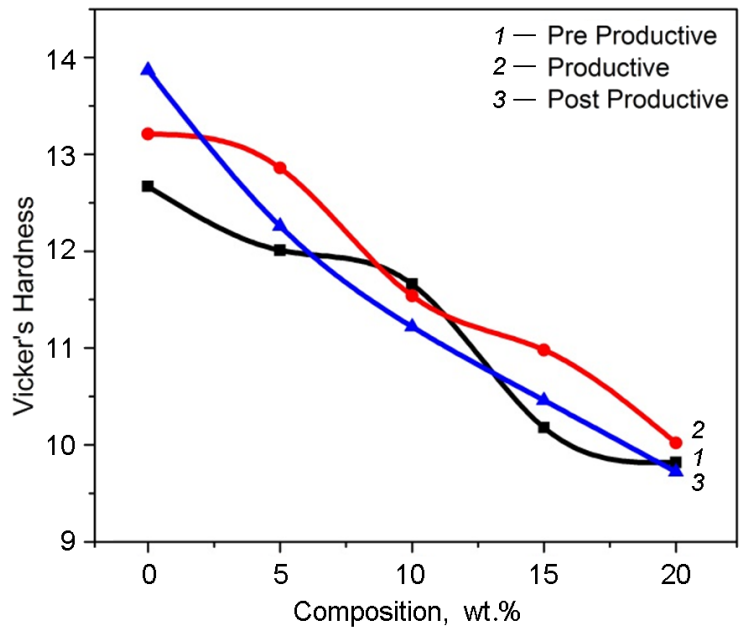

Fig. 4. The relationship between the Vicker's hardness and various composition of sugar palm fiber for pre productive, productive and post productive sugar palms.

Tabel 5. Element content of sugar palm tree fiber

\begin{tabular}{|c|c|c|c|c|c|}
\hline $\begin{array}{c}\# \\
\text { Chanel } \\
\end{array}$ & $\begin{array}{c}\text { Energy } \\
(\mathrm{keV})\end{array}$ & Element & \multicolumn{2}{|c|}{$T_{1 / 2}$} & $\begin{array}{c}\sigma_{t h} \\
\text { (barn) }\end{array}$ \\
\hline 6105.03 & 1642.04 & $\mathrm{Cl}-38$ & 37.25 & $\min$. & 0.423 \\
\hline 6746.79 & 1809.73 & $M n-56$ & 2.58 & $\mathrm{~h}$ & 13.2 \\
\hline 5678.69 & 1524.06 & $K-42$ & 12.36 & $\mathrm{~h}$ & 1.45 \\
\hline 2065.19 & 554.27 & $\mathrm{Br}-82$ & 35.3 & $\mathrm{~h}$ & 2.58 \\
\hline 1224.05 & 328.52 & La-140 & 40.27 & $\mathrm{~h}$ & 9.34 \\
\hline 1036.58 & 319.96 & $\mathrm{Cr}-51$ & 27.7 & $\mathrm{~h}$ & 15.2 \\
\hline 4811.34 & 1291.30 & $\mathrm{Fe}-59$ & 44.5 & $\mathrm{~h}$ & 1.31 \\
\hline 1038.72 & 278.78 & $\mathrm{Hg}-203$ & 46.61 & $\mathrm{~h}$ & 4.35 \\
\hline 3313.16 & 889.21 & Sc-46 & 83.81 & hours & 26.3 \\
\hline 4155.87 & 1115.38 & $\mathrm{Zn}-65$ & 243.9 & hours & 0.726 \\
\hline
\end{tabular}

was irradiated in the Neutron Radiography is given in the following Table 5 .

Qualitatively, based on the neutron activation analysis at Table 5 , several elements were identified such as $\mathrm{Cl}, \mathrm{Mn}, \mathrm{K}, \mathrm{Br}$, $\mathrm{La}, \mathrm{Cr}, \mathrm{Fe}, \mathrm{Hg}$, $\mathrm{Sc}$ and $\mathrm{Zn}$ on the composite containing sugar palm fibers enforced by polyester resin.

\subsection{Neutron absorption by sugar palm} fiber composite

In order to obtain the absorption by sugar palm fiber composite, all samples were placed in the SN-3 to be irradiated. The average of neutron beam counts as a function of sample thickness was depicted in the following Table 6, Table 7, Fig. 5 and Fig. 6.

The counts of neutron beams decreased as the content of sugar palm fibers in-

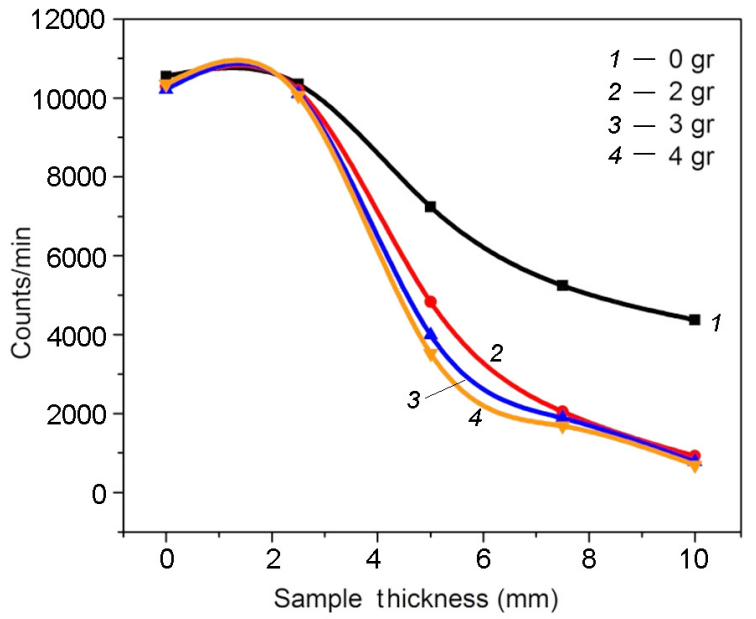

Fig. 5. The relationship between average counts as a function of thickness for samples containing $0,2,3$ and $4 \mathrm{gr}$ of sugar palm fibers, respectively.

Table 6 . The average counts/min for various weight of fibers

\begin{tabular}{|c|c|c|c|c|c||}
\hline \multirow{2}{*}{$\begin{array}{c}\text { \# of } \\
\text { blok }\end{array}$} & $\begin{array}{c}\text { Sampel } \\
\text { tickness } \\
(\mathrm{mm})\end{array}$ & \multicolumn{4}{|c|}{$\mathrm{W}(\mathrm{g})$} \\
\cline { 3 - 6 } & 0 & 10550 & 10291 & 10215 & 10352 \\
\hline 0 & 0 & 10352 & 10192 & 10109 & 10059 \\
1 & 2.5 & 7238 & 4828 & 3989 & 3525 \\
2 & 5.0 & 5243 & 2049 & 1884 & 1681 \\
3 & 7.5 & 4376 & 925 & 775 & 691 \\
4 & 10.0 & 435 & \multicolumn{4}{|c|}{} \\
\hline
\end{tabular}

Tabel 7. Average counts for various length of fibers

\begin{tabular}{|c|c|c|c|c|}
\hline \multirow{3}{*}{$\begin{array}{c}\text { No. } \\
\text { of } \\
\text { block }\end{array}$} & \multirow{2}{*}{$\begin{array}{c}\text { Sampel } \\
\text { thickness } \\
(\mathrm{mm})\end{array}$} & \multicolumn{3}{|c|}{ Counts $/ \mathrm{min}$} \\
\hline & & $\begin{array}{c}L= \\
0.5 \mathrm{~cm}\end{array}$ & $\begin{array}{c}L= \\
1.0 \mathrm{~cm}\end{array}$ & $\begin{array}{c}L= \\
1.5 \mathrm{~cm}\end{array}$ \\
\hline & Background & 4 & 2 & 3 \\
\hline 0 & 0 & 10501 & 10453 & 10288 \\
\hline 1 & 2.5 & 4346 & 2791 & 3998 \\
\hline 2 & 5.0 & 1665 & 745 & 1400 \\
\hline 3 & 7.5 & 682 & 235 & 536 \\
\hline 4 & 10.0 & 283 & 66 & 203 \\
\hline
\end{tabular}

creased. This fact implies that the composites containing sugar palm fibers can be used as shield materials for neutron beams. However, there was no effect on various length of fiber in decreasing beam counts. Based from Fig. 5 and Fig. 6 resulted that addition of weight with decreased counts/min. It indicated that sugar palm tree fiber has abilty for neutron shielding [14]. 


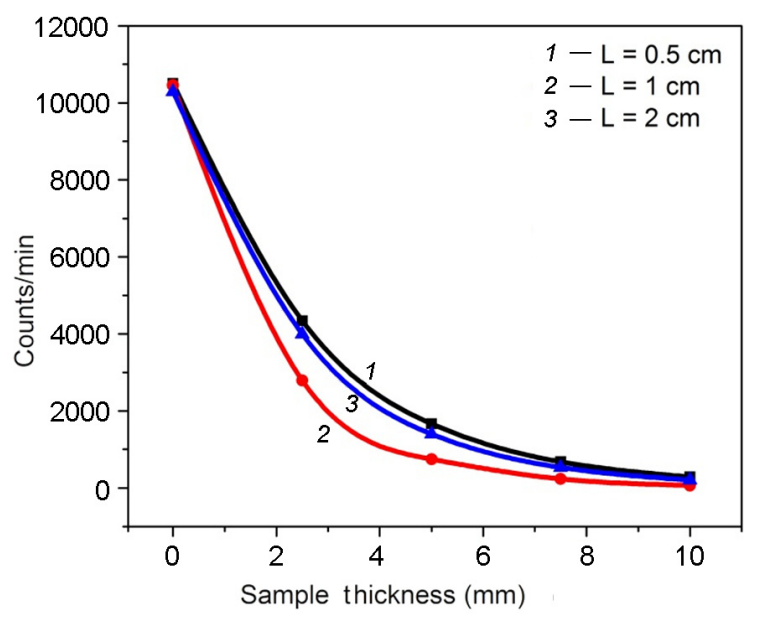

Fig. 6. The relationship between average counts as a function of thickness for samples containing $0.5,1.0,2.0 \mathrm{~cm}$ in length, respectively.

\section{Conclusions}

The mechanical characteristics of a fibrous composite material based on sugar palm fiber (Arenga pinnata) reinforced with polyester resin have been studied and determined. The chemical composition of sugar palm was determined, with content of cellulose, hemicellulose and lignin being $47.8 \%$, $6.5 \%, 22.3 \%$, respectively.

By neutron activation analysis, it was found that the sugar palm fiber obtained from the postproductive palm tree contains a number of chemical elements, such as $\mathrm{Cl}$, $\mathrm{Mn}, \mathrm{K}, \mathrm{Br}$, La, Cr, Fe, Hg, Sc and $\mathrm{Zn}$.
Due to high content of lignin (carbon), this material can be used for protection against thermal neutrons.

Acknowledgment. This work is partly supported by Universitas Sumatera Utara, Medan, Indonesia.

\section{References}

1. B.Neher, M.R.Bhuiyan, H.Kabir, R.Mater. Sci.Appl., 39 (2014).

2. B.F.Yousif, Int.J.Mod.Phys. B, 24, 23 (2010).

3. I.Mukhtar, Z.Leman, M.R.Ishak, E.S.Zainudin, BioResources, 11, 10756 (2016).

4. S.M.Hejazi, M.Sheikhzadeh, S.M.Abtahi, A.Zadhoush, Constr. Build. Mater., 30, 100 (2012).

5. S.Kalia, B.S.Kaith, I.Kaur, Polym.Eng.Sci., 49, 1253 (2009).

6. R.Akter, R.Sultana, Z.Alam, Int.J.Eng.Technol., 13, 122 (2013).

7. D.Gosset, P.Herter, V.Motte, Nucl.Instr. Meth. Phys. Res. B, Beam Interact. with Mater. Atoms, 434, 66 (2018).

8. P.McKendry, Bioresource Techn., 83, 37 (2002).

9. N.Reddy, Y.Yang, Trends in Biotechnology, 23, 22 (2005).

10. N.Martin, N.Mouret, P.Davies, C.Baley, Ind. Crops Prod., 49, 755 (2013).

11. A.Ticoalu, T.Aravinthan, F.Cardona, J.Reinf. Plast. Compos., 33, 179 (2014).

12. H.N.Dhakal, Z.Y.Zhang, M.O.W.Richardson, Compos.Sci.Techn., 67, 1674 (2007).

13. M.R.Ishak, S.M.Sapuan, Z.Leman et al., Carbohydrate Polymers, 91, 699 (2013).

14. S.U.El-Kameesy, W.A.Kansouh, E.Salama et al., J.Appl. Math. Phys., 5, 596 (2017). 